\title{
Antimicrobial Potential and Chemical Characterization of Serbian Liverwort (Porella arboris-vitae): SEM and TEM Observations
}

\author{
Amit Kumar Tyagi, ${ }^{1,2}$ Danka Bukvicki, ${ }^{1,3}$ Davide Gottardi, ${ }^{1}$ Milan Veljic, ${ }^{3}$ \\ Maria Elisabetta Guerzoni, ${ }^{1}$ Anushree Malik, ${ }^{2}$ and Petar D. Marin ${ }^{3}$ \\ ${ }^{1}$ Dipartimento di Scienze degli Alimenti, Università degli Studi di Bologna, Sede di Cesena, Piazza G. Goidanich 60, \\ 47023 Cesena, Italy \\ ${ }^{2}$ Applied Microbiology laboratory, Centre for Rural Development and Technology, Indian Institute of Technology Delhi, \\ New Delhi 110 016, India \\ ${ }^{3}$ Institute of Botany and Botanical Garden "Jevremovac", Faculty of Biology, University of Belgrade, Studentski trg 16, \\ 11000 Belgrade, Serbia
}

Correspondence should be addressed to Danka Bukvicki; dankabukvicki@bio.bg.ac.rs

Received 29 October 2012; Revised 6 December 2012; Accepted 6 December 2012

Academic Editor: Vincenzo De Feo

Copyright (C) 2013 Amit Kumar Tyagi et al. This is an open access article distributed under the Creative Commons Attribution License, which permits unrestricted use, distribution, and reproduction in any medium, provided the original work is properly cited.

\begin{abstract}
The chemical composition of Porella arboris-vitae extracts was determined by solid phase microextraction, gas chromatographymass spectrometry (SPME GC-MS), and 66 constituents were identified. The dominant compounds in methanol extract of $P$. arboris-vitae were $\beta$-caryophyllene (14.7\%), $\alpha$-gurjunene (10.9\%), $\alpha$-selinene (10.8\%), $\beta$-elemene (5.6\%), $\gamma$-muurolene (4.6\%), and allo-aromadendrene (4.3\%) and in ethanol extract, $\beta$-caryophyllene (11.8\%), $\alpha$-selinene $(9.6 \%), \alpha$-gurjunene (9.4\%), isopentyl alcohol (8.8\%), 2-hexanol (3.7\%), $\beta$-elemene (3.7\%), allo-aromadendrene $(3.7 \%)$, and $\gamma$-muurolene $(3.3 \%)$ were the major components. In ethyl acetate extract of $P$. arboris-vitae, undecane (11.3\%), $\beta$-caryophyllene (8.4\%), dodecane (6.4\%), $\alpha$-gurjunene (6\%), 2-methyldecane (5.1\%), hemimellitene (4.9\%), and D-limonene (3.9\%) were major components. The antimicrobial activity of different $P$. arboris-vitae extracts was evaluated against selected food spoilage microorganisms using microbroth dilution method. The Minimal Inhibitory Concentration (MIC) varied from 0.5 to $1.5 \mathrm{mg} / \mathrm{mL}$ and 1.25 to $2 \mathrm{mg} / \mathrm{mL}$ for yeast and bacterial strains, respectively. Significant morphological and ultrastructural alterations due to the effect of methanolic and ethanolic $P$. arborisvitae extracts on $S$. Enteritidis have also been observed by scanning electron microscope and transmission electron microscope, respectively. The results provide the evidence of antimicrobial potential of $P$. arboris-vitae extracts and suggest its potential as natural antimicrobial agents for food preservation.
\end{abstract}

\section{Introduction}

Foodborne diseases mediated by food spoilage microorganisms are a major challenge in developing as well as developed countries [1]. Increasing concern about potentially harmful synthetic as compared with low mammalian toxicity and less environmental effects of the natural ingredients has led to their wide public acceptance [2]. In this regard, certain plant extracts or essential oils with notable antimicrobial activity can be used to delay or inhibit the growth of pathogenic and/or toxin producing microorganisms in food $[3,4]$.
Apart from higher plants, liverworts also contain certain natural compounds or derivatives potentially responsible for tubulin polymerization inhibitory, muscle relaxing, and antimicrobial activity. Liverworts are used as folk medicine worldwide [5].

Liverwort species are rich source of new secondary metabolites and produce a variety of sesquiterpenoids, possessing the bicyclo[4.3.0]nonane moiety such as acutifolone, bisacutifolone, pinguisenol, and chiloscyphone [6]. These natural products have unique structures including the cis-oriented 
continuous substitutions in the bicyclo[4.3.0]nonane structure. Although, several liverworts have been used as medicinal plants [7], only $10 \%$ of the liverworts have yet been studied systematically [5]. Porella, family Porellaceae (Hepaticae), consists of pungent and nonpungent leafy-stem liverworts widespread in the tropical, subtropical, and temperate regions of the world. Most Porella species are rich sources of sesqui- and diterpenoids [8,9], many of which show interesting biological activities $[10,11]$. To the best of our knowledge, there are no previous reports either on chemical characterization or on antimicrobial potential of Porella arboris-vitae liverwort.

In the present study, the chemical composition of $P$. arboris-vitae has been analyzed by SPME GC-MS. The antimicrobial activity of different extracts of $P$. arboris-vitae against selected food spoiling and pathogenic microorganisms has been evaluated. Further to investigate whether $P$. arboris-vitae extracts act by interfering the outer cell wall of bacterial cell, scanning electron microscopy (SEM) and transmission electron microscopy (TEM) have been used. Microscopic techniques provide the unique evidence of the antimicrobial potential of $P$. arboris-vitae extracts.

\section{Material and Method}

2.1. Chemicals and Plant Materials. Analytical grade chemical reagents (methanol, ethanol, and ethyl acetate used for livewort extraction were purchased from Sigma-Aldrich $\mathrm{GmbH}$ (Germany). For antimicrobial activity, the different dry extracts were dissolved in dimethyl sulphoxide (DMSO) (Sigma-Aldrich GmbH, Germany). For yeast and bacterial cultivation, yeast extract peptone dextrose (YPD) and tryptic soy broth (TSB) (Merck KgaA Darmstad, Germany) were used, respectively.

The samples of Porella arboris-vitae (With.) Grolle were collected from Derventa, Bajina Bašta (Serbia) in 2010. A voucher specimen (No. 16640) has been deposited in herbarium at Institute of Botany and Botanical Garden "Jevremovac," University of Belgrade. Material was dried at room temperature for further use.

2.2. Extracts Preparation. Dried plants were pulverized into fine powder using an electric blender. Powdered material $(5 \mathrm{~g})$ was extracted with $100 \mathrm{~mL}$ of methanol, ethanol, or ethyl acetate for $24 \mathrm{~h}$ at room temperature. After $24 \mathrm{~h}$, the mixture was filtered through Whatman filter paper No. 1 . The solvents were evaporated from extracts using rotary vacuum evaporator (Laborota 4001 , Heidolph) at $40^{\circ} \mathrm{C}$. The yields of the extracts were $6.54 \%, 3.26 \%$, and $1.28 \%$ for methanol, ethanol, and ethyl acetate extract, respectively. The obtained extracts were stored at $4^{\circ} \mathrm{C}$ for further observations.

\subsection{Solid Phase Microextraction Gas Chromatographic-} Mass Spectrometry (SPME GC-MS) Analysis. A divinyl benzene/carboxen/polydimethyl siloxane (DVB/CAR/PDMS) coated stable flex fiber $(65 \mu \mathrm{m})$ and a manual SPME holder (Supelco Inc., Bellefonte, PA, USA) were used in this study after preconditioning according to the manufacturer's instruction manual. Before each headspace sampling, the fiber was exposed to the GC inlet for $5 \mathrm{~min}$ for thermal desorption at $250^{\circ} \mathrm{C}$.

Samples $(5 \mathrm{mg})$ were put into sealed vials $(20 \mathrm{~mL})$ and then equilibrated for $10 \mathrm{~min}$ at $40^{\circ} \mathrm{C}$. The SPME fiber was exposed to each sample for $10 \mathrm{~min}$ by manually penetrating the septum and the fiber was inserted into the injection port of the GC for $10 \mathrm{~min}$ for desorption. GC-MS analyses were carried out on an Agilent 6890 gas chromatograph (Agilent Technologies, Palo Alto, CA, USA) coupled to an Agilent 5970 mass selective detector operating in electron impact mode (ionization voltage, $70 \mathrm{eV}$ ). A Chrompack CP Wax 52 CB capillary column (50 m length, $0.32 \mathrm{~mm}$ i.d., $1.2 \mu \mathrm{m}$ df) was used (Chrompack, Middelburg, The Netherlands). The temperature program was $50^{\circ} \mathrm{C}$ for $0 \mathrm{~min}$, then programmed at $5^{\circ} \mathrm{C} / \mathrm{min}$ to $230^{\circ} \mathrm{C}$ for $10 \mathrm{~min}$. Injector, interface, and ion source temperatures were 250,250 , and $230^{\circ} \mathrm{C}$, respectively. Injections were performed with a split ratio of $1: 50$ and helium $(1 \mathrm{~mL} / \mathrm{min})$ as the carrier gas. Identification of chemical compounds was carried out by comparison of the mass spectra with mass spectra available on database of NIST05, WILEY8 libraries, and those of pure standards.

2.4. Microbial Strains. Different bacterial (Salmonella Enteritidis 155, Escherichia coli 555, and Listeria monocytogenes 56Ly) and yeast strains (Saccharomyces cerevisiae 635, Zygosacharomyces bailii 45, Aerobasidium pullulans L6F, Pichia membranaefaciens OC71, Pichia membranaefaciens OC70, Pichia anomala DBVPG3003, and Yarrowia lipolytica RO13) were obtained from the strain collection of the Dipartimento di Scienze degli Alimenti of Bologna University, Italy and used to evaluate the effect of liverwort extracts. Yeast strains were grown in YPD at $28^{\circ} \mathrm{C}$ for $48 \mathrm{~h}$ while bacterial strains were grown in TSB at $35^{\circ} \mathrm{C}$ for $24 \mathrm{~h}$. After harvesting, microbial cells were suspended in sterile physiological water and used immediately.

\subsection{Determination of Minimal Inhibitory Concentration} (MIC) by Microdilution Method. In order to investigate the antimicrobial activity of the extracts, the modified microdilution technique was used [12]. MIC determination was performed by microbroth dilution technique using 96-well microtitre plates. The extracts were dissolved with $0.5 \%$ DMSO and added in TSB and YPD broth with bacterial $\left(10^{6} \mathrm{cfu} / \mathrm{mL}\right)$ and yeasts $\left(10^{5} \mathrm{cfu} / \mathrm{mL}\right)$ inoculum, respectively. The microplates were incubated either at $32^{\circ} \mathrm{C}$ for $48 \mathrm{~h}$ (bacteria) or at $28^{\circ} \mathrm{C}$ for $72 \mathrm{~h}$ (yeasts). The lowest concentrations without visible growth were defined as MIC. Further, Minimal Bactericidal Concentration (MBC)/Minimal Yeast-cidal Concentration (MYC) of the extracts have been evaluated. MBC/MYC values were defined as the minimal concentrations of extract not allowing the microbial growth on agar medium after a particular incubation at optimal temperature. DMSO was used as negative control.

\subsection{Preparation of Samples for Scanning Electron Microscopy} and Transmission Electron Microscopy. S. Enteritidis cells were incubated for $14 \mathrm{~h}$ in TSB at $30^{\circ} \mathrm{C}$ and $120 \mathrm{rpm}$. The suspension was divided into three portions. In two portions, 
methanolic and ethanolic $P$. arboris-vitae extracts at MIC level $(1.25$ and $1.25 \mathrm{mg} / \mathrm{mL}$, resp.) $)$ were added and third portion was left untreated as a control. These suspensions were incubated at $30^{\circ} \mathrm{C}$ for $8 \mathrm{~h}$.

For investigating the effect of methanolic and ethanolic $P$. arboris-vitae extract, all the treated and untreated cells were harvested by centrifugation and were prefixed with a $2.5 \%$ glutaraldehyde solution overnight at $4^{\circ} \mathrm{C}$. After this, the cells were again harvested by centrifugation and washed three times with $0.1 \mathrm{M}$ sodium phosphate buffer solution ( $\mathrm{pH}$ 7.2). Now each resuspension was serially dehydrated with 25,50 , 75,90 , and $100 \%$ ethanol, respectively. Then, cells were dried at "critical point."

For SEM observation, a thin film of cells was smeared on a silver stub. The samples were gold-covered by cathodic spraying (Polaron gold). Morphology of the $S$. Enteritidis cells was observed on a scanning electronic microscope (ZEISS EVO 50). The SEM observation was done under the following analytical condition: $\mathrm{EHT}=20.00 \mathrm{kV}, \mathrm{WD}=9.5 \mathrm{~mm}$, and Signal $\mathrm{A}=\mathrm{SE}_{1}$.

For TEM observation, the pellet was postfixed in $1 \%$ osmium tetraoxide for $30 \mathrm{~min}$, washed with phosphate buffer solution ( $\mathrm{pH} 7.2$ ), serially dehydrated in ethanol, and embedded in Epon-Araldite resin for making the blocks of the cells pellet. Ultrathin $(50-100 \mathrm{~nm})$ sections of $S$. Enteritidis cells were stained with uranyl acetate and lead citrate and observed under a Philips transmission electron microscope (CM-10) at $100 \mathrm{eV}$ and direct magnification of $50.00 \mathrm{k}$.

2.7. Statistical Analyses. All the experiments were done in triplicate and repeatability was established. Significance of differences among treatments $(P \leq 0.05)$ was analysed using one way ANOVA (SPSS, 10.0 version).

\section{Results and Discussion}

3.1. Chemical Composition of Methanol, Ethanol, and Ethyl Acetate Extracts. More than 65 compounds of P. arborisvitae were identified by the SPME GC-MS analysis of different extracts. The main components with their percentages and retention indices are listed in Table 1 . In methanol extract of $P$. arboris-vitae, 43 components were identified, which represented $72.2 \%$ sesquiterpenes, $4.5 \%$ monoterpenes, $6.7 \%$ ketones, $0.5 \%$ nonterpene hydrocarbons, $1.87 \%$ aldehydes, $1.1 \%$ alcohols, and $11.7 \%$ others, about $98.6 \%$ of the total detected constituents. The major components were $\beta$-caryophyllene (14.7\%), $\alpha$-gurjunene $(10.9 \%), \alpha$ selinene (10.8\%), $\beta$-elemene (5.6\%), $\gamma$-muurolene (4.6\%), and allo-aromadendrene (4.3\%). 38 components were identified from the ethanol extract of $P$. arboris-vitae which represented 59.5\% sesquiterpenes, $4.8 \%$ monoterpenes, $2.5 \%$ nonterpene hydrocarbons, $19.6 \%$ alcohols, and 3.3\% ketones, about $98.7 \%$ of the total composition where $\beta$-caryophyllene $(11.8 \%), \alpha$-selinene $(9.6 \%), \alpha$-gurjunene $(9.4 \%)$, isopentyl alcohol (8.8\%), 2-hexanol (3.7\%), $\beta$-elemene (3.7\%), alloaromadendrene $(3.7 \%)$, and $\gamma$-muurolene $(3.3 \%)$ were the major components. 42 components were identified from
TABLE 1: Chemical composition of $P$. arboris-vitae extracts.

\begin{tabular}{|c|c|c|c|c|}
\hline Extracts & & ${ }^{\mathrm{a}} \mathrm{MeOH}$ & ${ }^{\mathrm{b}} \mathrm{EtOH}$ & ${ }^{\mathrm{c}}$ EtOAc \\
\hline \multicolumn{5}{|l|}{ Monoterpene hydrocarbons } \\
\hline D-limonene & 1208 & 2.62 & 2.23 & 3.89 \\
\hline$\beta$-phellandrene & 1220 & 1.07 & 1.67 & 0.00 \\
\hline p-cymene & 1281 & 0.78 & 0.85 & 2.89 \\
\hline Total & & 4.47 & 4.75 & 6.78 \\
\hline \multicolumn{5}{|l|}{ Sesquiterpene hydrocarbons } \\
\hline$\alpha$-cubebene & 1463 & 0.43 & 1.71 & 0.00 \\
\hline Cycloseychellene & 1513 & 2.36 & 2.69 & 1.86 \\
\hline$\beta$-bourbonene & 1519 & 1.45 & 1.25 & 0.00 \\
\hline$\alpha$-gurjunene & 1529 & 10.93 & 9.42 & 6.03 \\
\hline$\beta$-cubebene & 1531 & 0.18 & 0.55 & 0.00 \\
\hline Cyperene & 1534 & 0.52 & 0.00 & 0.00 \\
\hline D-longifolene & 1550 & 0.54 & 0.96 & 1.42 \\
\hline$\beta$-elemene & 1571 & 5.59 & 3.70 & 2.59 \\
\hline$\beta$-cubebene & 1574 & 0.29 & 0.00 & 0.75 \\
\hline Neoisolongifolene & 1588 & 2.75 & 1.85 & 0.80 \\
\hline$\beta$-caryophyllene & 1594 & 14.70 & 11.75 & 8.34 \\
\hline$\beta$-gurjunene & 1598 & 2.05 & 1.95 & 0.91 \\
\hline cis-thujopsene & 1616 & 1.04 & 0.00 & 0.00 \\
\hline Amorpha-4,11-diene & 1636 & 1.96 & 1.59 & 1.51 \\
\hline Allo-aromadendrene & 1642 & 4.25 & 3.70 & 2.13 \\
\hline$\beta$-farnesene & 1664 & 1.85 & 2.60 & 2.17 \\
\hline$\gamma$-muurolene & 1671 & 4.59 & 3.27 & 2.47 \\
\hline Aonarene & 1690 & 0.13 & 0.00 & 0.00 \\
\hline Aristolochene & 1709 & 0.29 & 0.00 & 0.00 \\
\hline Germacrene D & 1717 & 2.40 & 1.73 & 0.00 \\
\hline$\alpha$-selinene & 1724 & 10.76 & 9.57 & 4.21 \\
\hline$\gamma$-cadinene & 1752 & 0.24 & 0.49 & 0.00 \\
\hline Selina-3,7(11)-diene & 1763 & 0.26 & 0.00 & 0.93 \\
\hline$\beta$-bazzanene & 1794 & 1.49 & 0.75 & 0.57 \\
\hline Calamenene & 1855 & 1.15 & 0.00 & 0.87 \\
\hline Total & & 72.20 & 59.53 & 37.56 \\
\hline \multicolumn{5}{|l|}{ Nonterpene hydrocarbons } \\
\hline 2,6-Dimethylnonane & 989 & 0.00 & 0.00 & 1.16 \\
\hline 2,7,10-Trimethyldodecane & 1005 & 0.00 & 0.00 & 0.36 \\
\hline 5-Methyldecane & 1035 & 0.00 & 0.00 & 1.85 \\
\hline 2-Methyldecane & 1038 & 0.00 & 0.00 & 5.10 \\
\hline 3-Methyldecane & 1048 & 0.00 & 0.00 & 4.56 \\
\hline Undecane & 1091 & 0.23 & 0.86 & 11.27 \\
\hline 1,2-Diethylcyclooctane & 1128 & 0.00 & 0.00 & 0.28 \\
\hline 2,3-Dimethyldecane & 1142 & 0.00 & 0.00 & 0.75 \\
\hline Dodecane & 1190 & 0.13 & 0.00 & 6.34 \\
\hline 2-Phenylbutane & 1260 & 0.00 & 0.00 & 0.15 \\
\hline Tridecane & 1290 & 0.00 & 0.00 & 0.27 \\
\hline Hemimellitene & 1292 & 0.00 & 0.00 & 4.91 \\
\hline p-Propyltoluene & 1318 & 0.00 & 0.00 & 2.58 \\
\hline n-Butylbenzene & 1322 & 0.00 & 0.00 & 0.49 \\
\hline 2-Ethyl-p-xylene & 1368 & 0.00 & 0.00 & 3.7446 .82 \\
\hline 3,5-Diethyltoluene & 1402 & 0.00 & 0.00 & 0.53 \\
\hline
\end{tabular}


TABLE 1: Continued.

\begin{tabular}{|c|c|c|c|c|}
\hline Extracts & & ${ }^{\mathrm{a}} \mathrm{MeOH}$ & ${ }^{\mathrm{b}} \mathrm{EtOH}$ & ${ }^{\mathrm{c}} \mathrm{EtOAc}$ \\
\hline Durene & 1488 & 0.14 & 1.63 & 2.48 \\
\hline Total & & 0.50 & 2.49 & \\
\hline \multicolumn{5}{|l|}{ Alcohols } \\
\hline 1-Propanol & 1031 & 0.00 & 1.53 & 0.00 \\
\hline 1-Ethoxy-2-propanol & 1168 & 0.00 & 3.02 & 0.00 \\
\hline Isopentyl alcohol & 1203 & 0.00 & 8.75 & 0.00 \\
\hline 2-Hexanol & 1214 & 0.00 & 3.68 & 0.00 \\
\hline 1-Isopropoxy-2-propanol & 1244 & 0.00 & 2.35 & 0.00 \\
\hline 1-Octen-3-ol & 1441 & 0.88 & 0.24 & 0.00 \\
\hline $\begin{array}{l}\text { 1-(2-Methoxypropoxy)-2- } \\
\text { propanol }\end{array}$ & 1510 & 0.16 & 0.00 & 0.00 \\
\hline $\begin{array}{l}\text { Trans-1,10-Dimethyl-trans-9- } \\
\text { Decalinol }\end{array}$ & 1859 & 0.07 & 0.00 & 0.00 \\
\hline Total & & 1.11 & 19.57 & 0.00 \\
\hline \multicolumn{5}{|l|}{ Ketones } \\
\hline Methyl Isobutyl ketone & 1007 & 1.00 & 0.84 & 0.00 \\
\hline 3-Butyl-cyclohexanone & 1124 & 0.00 & 0.00 & 1.06 \\
\hline 4-Methyl-3-penten-2-one & 1146 & 2.96 & 1.06 & 0.00 \\
\hline 2,2,6-Trimethylcyclohexanone & 1336 & 0.12 & 0.00 & 0.00 \\
\hline Cyclocolorenone $\langle$ epi- $\rangle$ & 2394 & 2.63 & 1.44 & 0.54 \\
\hline Total & & 6.71 & 3.34 & 1.60 \\
\hline \multicolumn{5}{|l|}{ Aldehydes } \\
\hline Hexanal & 1097 & 1.87 & 0.68 & 0.00 \\
\hline Furfural & 1470 & 0.00 & 0.99 & 0.00 \\
\hline Total & & 1.87 & 1.67 & 0.00 \\
\hline \multicolumn{5}{|l|}{ Others } \\
\hline Acetic acid & 1448 & 7.75 & 7.09 & 3.33 \\
\hline Hexanoic acid & 1840 & 1.97 & 1.69 & 0.37 \\
\hline Lanceol acetate $\langle\mathrm{Z}-\rangle$ & 1852 & 0.14 & 0.00 & 0.00 \\
\hline Caryophylene oxide & 2019 & 1.84 & 0.95 & 0.84 \\
\hline Dodecanoic acid & 2461 & 0.00 & 0.12 & 0.93 \\
\hline Octanoic acid & 2083 & 0.00 & 0.00 & 0.13 \\
\hline Total & & 11.70 & 9.85 & 5.60 \\
\hline Total identified compounds & & 98.56 & 98.71 & 98.36 \\
\hline
\end{tabular}

RI: retention index on CP WAX $52 \mathrm{CB}$ capillary column; ${ }^{\mathrm{a}} \mathrm{MeOH}$ : methanol extract; ${ }^{\mathrm{b}} \mathrm{EtOH}$ : ethanol extract; ${ }^{\mathrm{c}} \mathrm{EtOAc}$ : ethyl acetate extract.

the ethyl acetate extract of $P$. arboris-vitae which represented $46.8 \%$ nonterpene hydrocarbons, $37.6 \%$ sesquiterpenes, $6.8 \%$ monoterpenes, and $1.6 \%$ ketones where undecane $(11.3 \%), \beta$-caryophyllene $(8.4 \%)$, dodecane $(6.4 \%)$, $\alpha$-gurjunene (6\%), 2-methyldecane (5.1\%), hemimellitene (4.9\%), and D-limonene (3.9\%) were the main compounds.

The presence of various monoterpenes, sesquiterpenes, and diterpenes in liverworts has been reported in earlier works [13-15]. These terpenes possess various kinds of biological activity and are beneficial for the health [16]. In the present study, $P$. arboris-vitae extract has shown the presence of many kinds of sesquiterpenoids which are ubiquitous in other liverworts. Higher percentage of sesquiterpenoids hydrocarbons could be responsible for higher antimicrobial activity.
3.2. Antimicrobial Activity. The MIC and MBC/MYC of different $P$. arboris-vitae extracts were determined against various bacterial (S. Enteritidis, E. coli, and L. monocytogenes) and yeast ( $S$. cerevisiae, $Z$. bailii, A. pullulans, P. membranaefaciens, $P$. anomala, and $Y$. lipolytica) strains. These MIC and MBC/MYC values are shown in Table 2. Different $P$. arboris-vitae extracts exhibited concentration-dependent growth inhibition.

For the bacterial strains, the MIC varied from 1.25 to $2 \mathrm{mg} / \mathrm{mL}$ (Table 2). The MIC of different $P$. arboris-vitae extracts for Gram-positive bacteria (L. monocytogenes) was significantly $(P \leq 0.05)$ lesser than Gram-negative bacteria (S. Enteritidis, E. coli), that is, $1.25 \mathrm{mg} / \mathrm{mL}$ and $2 \mathrm{mg} / \mathrm{mL}$, respectively. However, MIC value of ethyl acetate extract for L. monocytogenes was significantly $(P \leq 0.05)$ higher than the methanol and ethanol extracts of $P$. arboris-vitae. The $\mathrm{MBC}$ of different extracts for bacterial strains varied from 2 to $3 \mathrm{mg} / \mathrm{mL}$. MIC for streptomycin was $0.02-0.05 \mathrm{mg} / \mathrm{mL}$ and the MBC was $0.10 \mathrm{mg} / \mathrm{mL}$. Higher MIC and MBC values of Gram-negative bacteria could be due to the presence of lipopolysaccharide cell envelope and highly hydrophilic cell membrane. Antimicrobial potential of 11 sesquiterpenoids, methanol and diethyl ether extract of Tahitian liverwort Mastigophora diclados was observed against Staphylococcus aureus NBRC 15035 and Bacillus subtilis NBRC 3134 where MIC of methanol and diethyl ether extract of $M$. diclados was 64 and $16 \mathrm{mg} / \mathrm{mL}$, respectively [17]. These MIC values are quit higher than those evaluated in present study.

The MIC of methanol, ethanol, and ethyl acetate extracts for yeast strains varied from $0.5-1 \mathrm{mg} / \mathrm{mL}, 1-1.25 \mathrm{mg} / \mathrm{mL}$, and $1-1.5 \mathrm{mg} / \mathrm{mL}$, respectively (Table 2 ). The MIC values also varied as per the yeast strains. $Z$. bailii, P. membranaefaciens OC 71, P. membranaefaciens OC 70, and P. anomala DBVPG 3003 showed higher MIC than other tested yeast strains for ethanolic and ethyl acetate $P$. arboris-vitae extracts, while methanolic $P$. arboris-vitae extract showed lesser MIC for $P$. anomala CBS 5759 and Y. lipolytica than other tested strains. Similar pattern was found for the MYC of different extracts against yeast strains, that is, MYC of ethyl acetate extract $\geq$ MYC of ethanolic extract $>$ MYC of methanolic extract of $P$. arboris-vitae. The commercial antibiotic cycloheximide was used as a control, which possessed much lesser MICs $(<0.05 \mathrm{mg} / \mathrm{mL})$ than the different extracts against selected yeast strains. In general, different $P$. arboris-vitae extracts showed substantial antimicrobial activity and yeast strains were more sensitive than bacterial strains (Table 2).

Comparison of the MIC/MBC of different extracts for same bacterial or yeast strain showed that in general ethyl acetate extract had lower antimicrobial activity. This could be correlated with the presence of sesquiterpenes hydrocarbons which was higher in methanol (72.2\%) and ethanol (59.5\%) extracts than ethyl acetate extract $(37.6 \%)$ of $P$. arboris-vitae. Earlier, Bukvicki et al. [18] also reported that high content of sesquiterpene components may account for the higher antimicrobial activity of methanol and ethanol extracts than ethyl acetate extract of liverwort. The presence of volatile sesquiterpene hydrocarbons such as $\beta$-selinene, $\alpha$-guaiene, $\alpha$-bisabolene, $\alpha$-cedrene, caryophyllene, $\alpha$-amorphene, $\alpha$ chamigrene, bulnesene, and valencene acted synergistically 
TABLE 2: Antimicrobial activity of liverwort P. arboris-vitae methanol, ethanol, and ethyl acetate extracts (mg/mL).

\begin{tabular}{|c|c|c|c|c|c|c|c|c|}
\hline \multirow{3}{*}{ Microorganisms } & \multicolumn{6}{|c|}{ P. arboris-vitae extract $(\mathrm{mg} / \mathrm{mL})$} & \multicolumn{2}{|c|}{ Control } \\
\hline & \multicolumn{2}{|c|}{$\mathrm{MeOH}$} & \multicolumn{2}{|c|}{$\mathrm{EtOH}$} & \multicolumn{2}{|c|}{ EtOAc } & \multirow{2}{*}{$\begin{array}{l}\text { Strep. } \\
\text { MIC }\end{array}$} & \multirow{2}{*}{$\begin{array}{c}\text { Cyclo. } \\
\text { MIC }\end{array}$} \\
\hline & MIC & $\mathrm{MBC} / \mathrm{MYC}$ & MIC & MBC/MYC & MIC & MBC/MYC & & \\
\hline S. Enteritidis 555 & 1.5 & 2 & 1.5 & 2 & 2 & 3 & 0.05 & - \\
\hline E. coli 155 & 1.5 & 2 & 1.5 & 2.5 & 2 & 3 & 0.05 & - \\
\hline L. monocytogenes $56 \mathrm{Ly}$ & 1.25 & 2 & 1.25 & 2 & 1.5 & 3 & 0.02 & - \\
\hline S. cerevisiae 635 & 1 & 1.5 & 1 & 2 & 1 & 2 & & $<0.05$ \\
\hline Z. bailii 45 & 1 & 1.5 & 1.25 & 2 & 1.5 & 2.5 & & $<0.05$ \\
\hline A. pullulans L6F & 1 & 1.5 & 1 & 2 & 1 & 2 & & $<0.05$ \\
\hline P. membranaefaciens OC 71 & 1 & 1.5 & 1.25 & 2.5 & 1.5 & 2.5 & & $<0.05$ \\
\hline P. membranaefaciens OC 70 & 1 & 1.5 & 1.25 & 2.5 & 1.5 & 2.5 & & $<0.05$ \\
\hline P. anomala CBS 5759 & 0.5 & 1 & 1 & 1.5 & 1.25 & 2 & & $<0.05$ \\
\hline P. anomala DBVPG 3003 & 1 & 1.5 & 1.25 & 2.5 & 1.25 & 2 & & $<0.05$ \\
\hline Y. lipolytica RO 13 & 0.5 & 1.5 & 1 & 1.5 & 1 & 1.5 & & 0.02 \\
\hline
\end{tabular}

MIC: minimal inhibitory concentration; MBC: minimal bactericidal concentration; MYC: Minimal Yeast-cidal Concentration (MYC); MeOH: methanolic extract; EtOH: ethanolic extract; EtOAc: ethyl acetate extract; Strep.: streptomycine; Cyclo.: cycloheximide.

to kill a broad range of plant and human pathogenic microorganisms [19]. In the present study, higher contents of these reported compounds were available in methanol and ethanol extract than the ethyl acetate extract of $P$. arboris-vitae, which support our results in regard to high antimicrobial activity of methanol extracts. Veljic et al. [20], also evaluated the antimicrobial activity of Ptilidium pulcherrimum methanol extract where the MIC for bacterial strains and fungal strains varied from $10-20 \mathrm{mg} / \mathrm{mL}$ and $0.5-2.5 \mathrm{mg} / \mathrm{mL}$, respectively. These results are higher as observed in present study.

\subsection{Morphological and Ultrastructural Alterations of S. Enteritidis}

3.3.1. Scanning Electron Microscopy (SEM) Observation. Bacterial cells treated with methanolic and ethanolic P. arborisvitae extract at MIC level showed considerable morphological alterations in comparison to the control (Figure 1). Control $S$. Enteritidis cells appeared intact, separated from each other, turgid, and complete with smooth surface (Figure 1(a)) while methanolic and ethanolic P. arboris-vitae extract treated cells appeared to be aggregated and partially deformed (Figures $1(\mathrm{~b})$ and $1(\mathrm{c})$ ), respectively. SEM pictures revealed the complete loss of turgidity and the cytoplasmic material from the bacterial cells. It seems due to the leakage of cytoplasmic material of the bacterial cells and the aggregate cells appeared as sludge. Similar observations indicating the aggregations of bacterial cells as a stress response upon exposure to negative air ions have been reported earlier [21], where complete leakage of cytoplasmic material and loss of turgidity were found due to the combined exposure of negative air ions and lemon grass oil vapours. Other authors [22, 23] also observed aggregation of bacterial cells by the exposure to antimicrobial compounds similar to the present results. These SEM micrographs confirmed the evidences of antimicrobial potential of $P$. arboris-vitae.
3.3.2. Transmission Electron Microscope (TEM) Observation. Further evidence of antibacterial potential of methanolic and ethanolic $P$. arboris-vitae extract has been obtained by TEM study (Figure 2). Untreated cells were studied as a control.

TEM photomicrographs of untreated $S$. Enteritidis cells show a regular outlined cell wall, plasma lemma lying closely to the cell wall (shown by arrows), and regularly distributed cytoplasm (Figure 2(a)). TEM photomicrographs of methanolic and ethanolic $P$. arboris-vitae extract treated bacterial cells revealed the variation in cell wall thickness and internal damages (Figures 2(b) and 2(c)). Methanolic extract treated bacterial cells (Figure 2(b)) showed extensive ultrastructural damages and wide range of abnormalities in comparison to ethanolic extract treated (Figure 2(c)) cells (shown by arrows). As shown in Figure 2, plasma lemma damaged and periplasmic space became larger and irregular in the treated cells. The cytoplasm appeared very dense at certain locations and unsymmetrically distributed in the cell (Figures 2(b) and 2(c)). At certain locations, the leakage of intracellular contents due to damage of cell envelop was also found (Figures 2(b) and 2(c)). This can also result from alteration in membrane permeability leading to draining out of the inner contents while the main structure of the outer membrane still remains intact.

Antimicrobial activity of various terpenes possesses discrete lipophilic characteristics and detectable water solubility may be potentiated by the fact that it can migrate across the aqueous extracellular medium, interact with, and damage lipid membranes. Since the outer layer of the Gram-negative bacteria is composed of lipopolysaccharide molecules and forms a hydrophilic permeability barrier providing protection against the effects of highly hydrophobic compounds [24], they may exhibit low sensibility of Gram-negative bacteria to the cytotoxic effect of the highly lipophilic monoterpenes. To the best of our knowledge, it is the first study where author tries to evaluate the ultrastructural changes in 


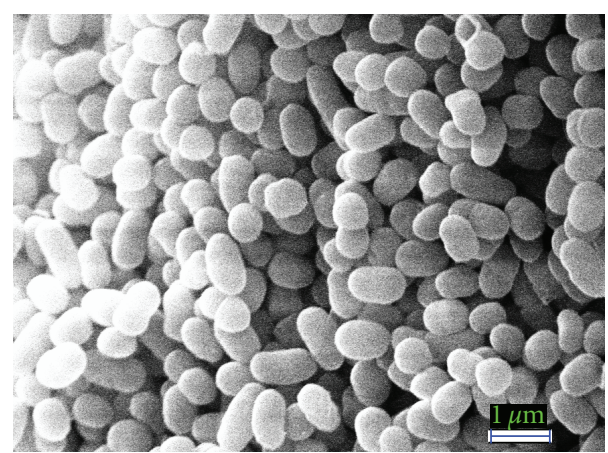

(a)

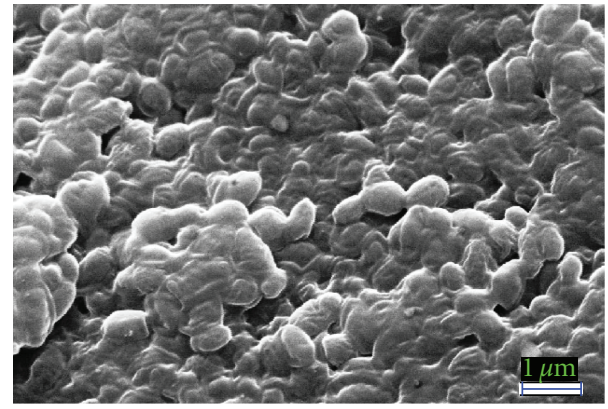

(b)

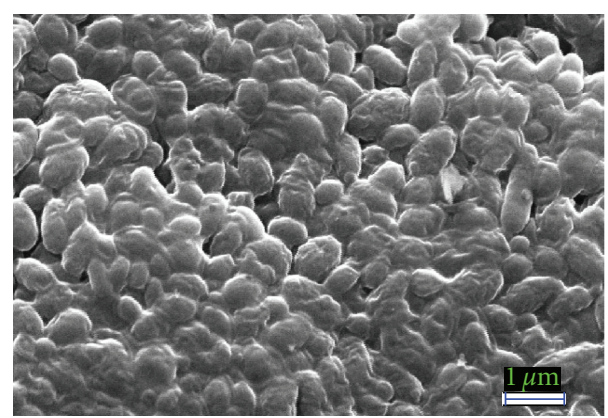

(c)

FIGURE 1: Scanning electron micrographs of untreated and treated $S$. Enteritidis cells. (a) Untreated cells with normal smooth surfaces $(\times 20 \mathrm{~K})$. (b) Shrinked aggregated and ruptured methanolic $P$. arboris-vitae extract treated cells $(\times 20 \mathrm{~K})$. (c) Shrinked aggregated and partially deformed ethanolic $P$. arboris-vitae extract treated cells $(\times 20 \mathrm{~K})$.

bacterial cells due to methanolic and ethanolic $P$. arborisvitae extracts.

\section{Conclusions}

Antimicrobial potential of European folk medicinal plant $P$. arboris-vitae extracts against various bacterial and yeast strains has been investigated employing different microscopic techniques. SEM and TEM micrographs of the methanolic and ethanolic $P$. arboris-vitae extract treated bacterial cells together show the evidence of rupture, cell lysis, and loss of cytoplasmic material. SEM examination revealed that shrinkage of the bacterial cell was apparent in the cells treated with $P$. arboris-vitae extracts, when compared to

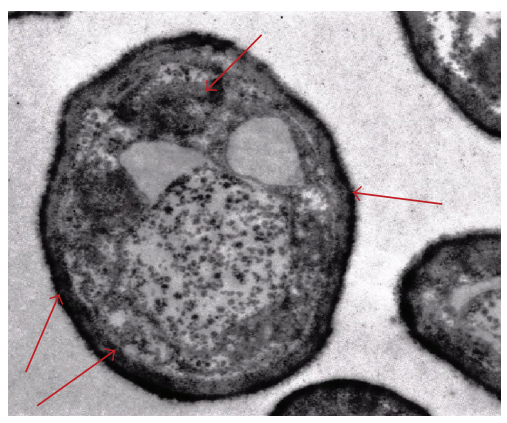

(a)

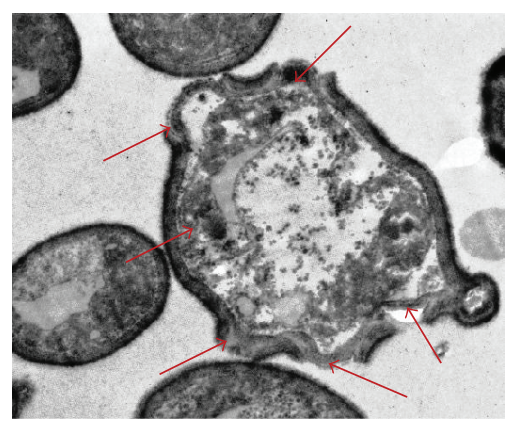

(b)

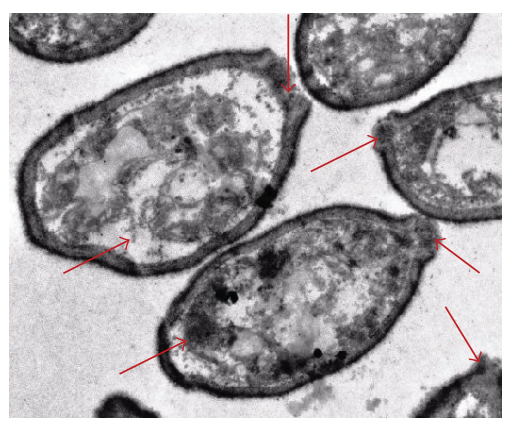

(c)

FIgURE 2: Transmission electron micrographs of untreated and treated $S$. Enteritidis cells. (a) Untreated cells having a regular outlined cell wall, plasma lemma lying closely to the cell wall, and regularly distributed cytoplasm (shown by arrows). (b) Methanolic P. arboris-vitae extract treated cells having extensive internal damage, unsymmetrical distributed cytoplasm, and larger and irregular periplasmic space (shown by arrows). (c) Ethanolic P. arboris-vitae extract treated cells having variable cell wall thickness appeared disrupted and variable periplasmic space (shown by arrows).

the untreated ones. Loss of turgidity and leakage of the cytoplasm from the bacterial cells were also observed by TEM investigations.

Presence of different biologically active chemical constituents was characterized with SPME GC-MS and revealed the possibility to use the $P$. arboris-vitae extract with food materials. However, further investigations to determine the interaction of $P$. arboris-vitae extract with different food components are necessary. Antimicrobial activity of $P$. arborisvitae extract should also be tested in real food systems for using it as a food preservative. 


\section{Acknowledgments}

This research work was financially supported by Ministry of Education and Science of Serbia (Project no. 173029) and Erasmus Mundus fellowship under EMECW to D. Bukvicki and A. K. Tyagi.

\section{References}

[1] A. K. Tyagi, A. Malik, D. Gottardi, and M. E. Guerzoni, "Essential oil vapour and negative air ions: a novel tool for food preservation," Trends in Food Science \& Technology, vol. 26, no. 2, pp. 99-113, 2012.

[2] P. A. Paranagama, K. H. T. Abeysekera, K. Abeywickrama, and L. Nugaliyadde, "Fungicidal and anti-aflatoxigenic effects of the essential oil of Cymbopogon citratus (DC.) Stapf. (lemongrass) against Aspergillus flavus Link isolated from stored rice," Letters in Applied Microbiology, vol. 37, no. 1, pp. 86-90, 2003.

[3] A. K. Tyagi and A. Malik, "Antimicrobial potential and chemical composition of Mentha piperita oil in liquid and vapour phase against food spoiling microorganisms," Food Control, vol. 22, no. 11, pp. 1707-1714, 2011.

[4] A. K. Tyagi and A. Malik, "Antimicrobial potential and chemical composition of Eucalyptus globulus oil in liquid and vapour phase against food spoilage microorganisms," Food Chemistry, vol. 126, no. 1, pp. 228-235, 2011.

[5] Y. Asakawa, "Liverworts-potential source of medicinal compounds," Medicinal Aromatic Plants, vol. 1, article e114, p. 3, 2012.

[6] J. Shiina and S. Nishiyama, "The first total synthesis of acutifolone A, a pinguisane-type sesquiterpenoid isolated from the Japanese liverwort Porella acutifolia subsp. tosana," Tetrahedron Letters, vol. 46, no. 45, pp. 7683-7686, 2005.

[7] J. M. Glime, Bryophyte Ecology. Volume 5: Uses, Michigan Technological University and the International Association of Bryologists, 2007.

[8] M. Toyota, A. Ueda, and Y. Asakawa, "Sesquiterpenoids from the liverwort Porella acutifolia subsp. Tosana," Phytochemistry, vol. 30, no. 2, pp. 567-573, 1991.

[9] D. N. Quang and Y. Asakawa, "Chemical constituents of the Vietnamese liverwort Porella densifolia," Fitoterapia, vol. 81, no. 6, pp. 659-661, 2010.

[10] Y. Asakawa, "Recent advances in phytochemistry of bryophytesacetogenins, terpenoids and bis(bibenzyl)s from selected Japanese, Taiwanese, New Zealand, Argentinean and European liverworts," Phytochemistry, vol. 56, no. 3, pp. 297-312, 2001.

[11] Y. Asakawa, "Phytochemistry of bryophytes: biologically active terpenoids and aromatic compounds from liverworts," in Phytochemicals in Human Health Protection, Nutrition, and Plant Defense, J. Romeo, Ed., pp. 319-342, Kluwer Academic, New York, NY, USA, 1999.

[12] National Committee for Clinical Laboratory Standards (NCCLS), "Performance standards for antimicrobial susceptibility testing; 9th International Supplement," Approved Standard M100-S9, National Committee for Clinical Laboratory Standards, Wayne, Pa, USA, 1999.

[13] F. Nagashima, K. Suda, and Y. Asakawa, "Cadinane-type sesquiterpenoids from the liverwort Scapania undulata," Phytochemistry, vol. 37, no. 5, pp. 1323-1325, 1994.

[14] S. Dagli, "Three diterpenes from the liverwort Nardia scalaris," KSU Journal of Science and Engineering, vol. 7, pp. 8-11, 2004.
[15] A. J. Barlow, B. J. Compton, U. Hertewich, S. D. Lorimer, and R. T. Weavers, "Sesquiterpenes from the New Zealand liverwort Lepidolaena hodgsoniae," Journal of Natural Products, vol. 68, no. 6, pp. 825-831, 2005.

[16] R. Paduch, M. Kandefer-Szerszeń, M. Trytek, and J. Fiedurek, "Terpenes: substances useful in human healthcare," Archivum Immunologiae et Therapiae Experimentalis, vol. 55, no. 5, pp. 315-327, 2007.

[17] I. Komala, T. Ito, F. Nagashima, Y. Yagi, and Y. Asakawa, "Cytotoxic, radical scavenging and antimicrobial activities of sesquiterpenoids from the Tahitian liverwort Mastigophora diclados (Brid.) Nees (Mastigophoraceae)," Journal of Natural Medicines, vol. 64, no. 4, pp. 417-422, 2010.

[18] D. Bukvicki, D. Gottardi, M. Veljic, P. D. Marin, L. Vannini, and M. E. Guerzoni, "Identification of volatile components of liverwort (Porella cordaeana) extracts using GC/MS-SPME and their antimicrobial activity," Molecules, vol. 17, no. 6, pp. 6982-6995, 2012.

[19] R. Kramer and W. R. Abraham, "Volatile sesquiterpenes from fungi: what are they good for?" Phytochemistry, vol. 11, pp. 15-37, 2012.

[20] M. Veljic, A. Ćirić, M. Soković, P. Janaćković, and P. D. Marin, "Antibacterial and antifungal activity of the liverwort (Ptilidium pulcherrimum) methanol extract," Archives of Biological Sciences, vol. 62, pp. 381-395, 2010.

[21] A. K. Tyagi and A. Malik, "Antimicrobial action of essential oil vapours and negative air ions against Pseudomonas fluorescens," International Journal of Food Microbiology, vol. 143, no. 3, pp. 205-210, 2010.

[22] P. Eaton, J. C. Fernandes, E. Pereira, M. E. Pintado, and F. X. Malcata, "Atomic force microscopy study of the antibacterial effects of chitosans on Escherichia coli and Staphylococcus aureus," Ultramicroscopy, vol. 108, no. 10, pp. 1128-1134, 2008.

[23] A. K. Tyagi and A. Malik, "Morphostructural damage in food spoiling bacteria due to the lemon grass oil and its vapour: SEM, TEM and AFM investigations," Evidence-Based Complementary and Alternative Medicine, vol. 2012, Article ID 692625, 12 pages, 2012.

[24] I. M. Helander, H. L. Alakomi, K. Latva-Kala et al., "Characterization of the action of selected essential oil components on gram-negative bacteria," Journal of Agricultural and Food Chemistry, vol. 46, no. 9, pp. 3590-3595, 1998. 


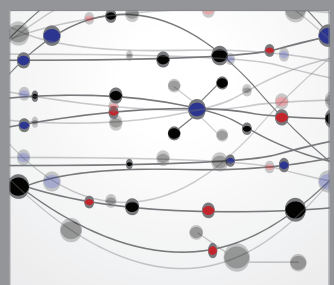

The Scientific World Journal
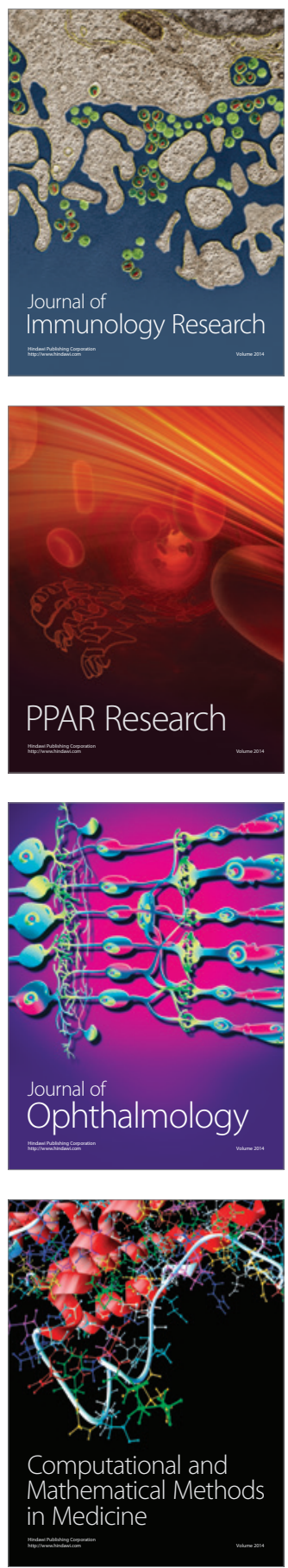

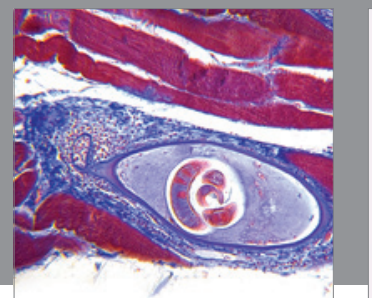

Gastroenterology

Research and Practice
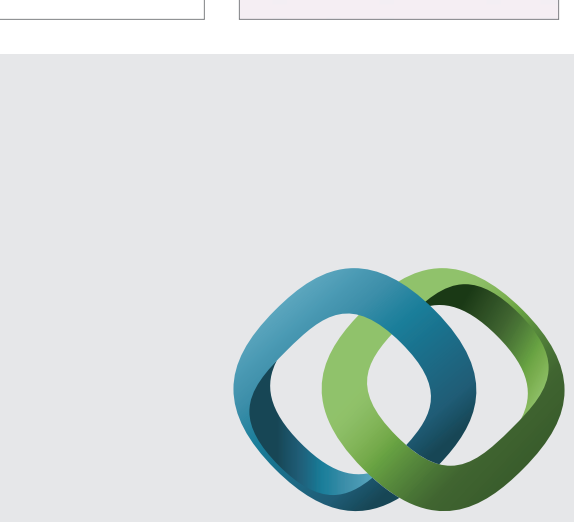

\section{Hindawi}

Submit your manuscripts at

http://www.hindawi.com
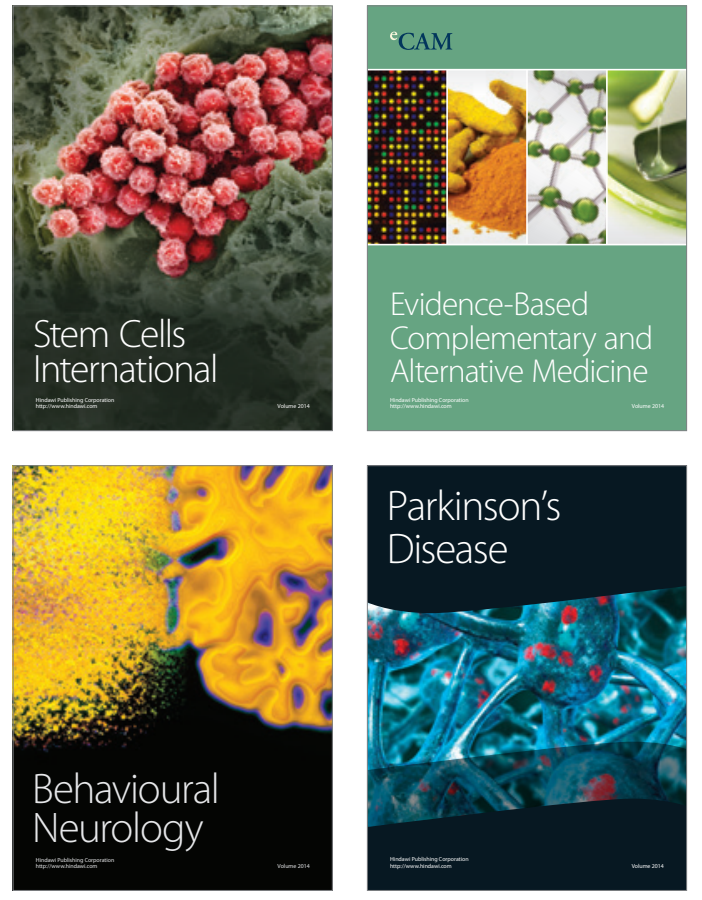
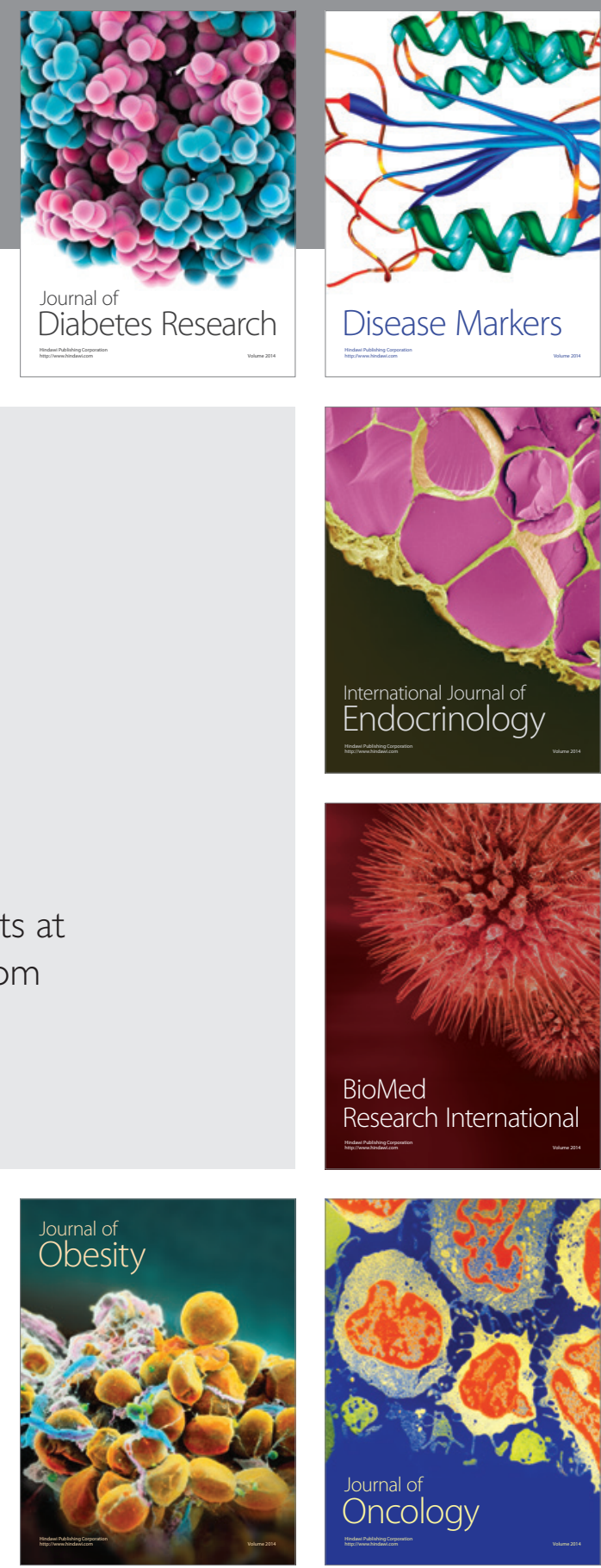

Disease Markers
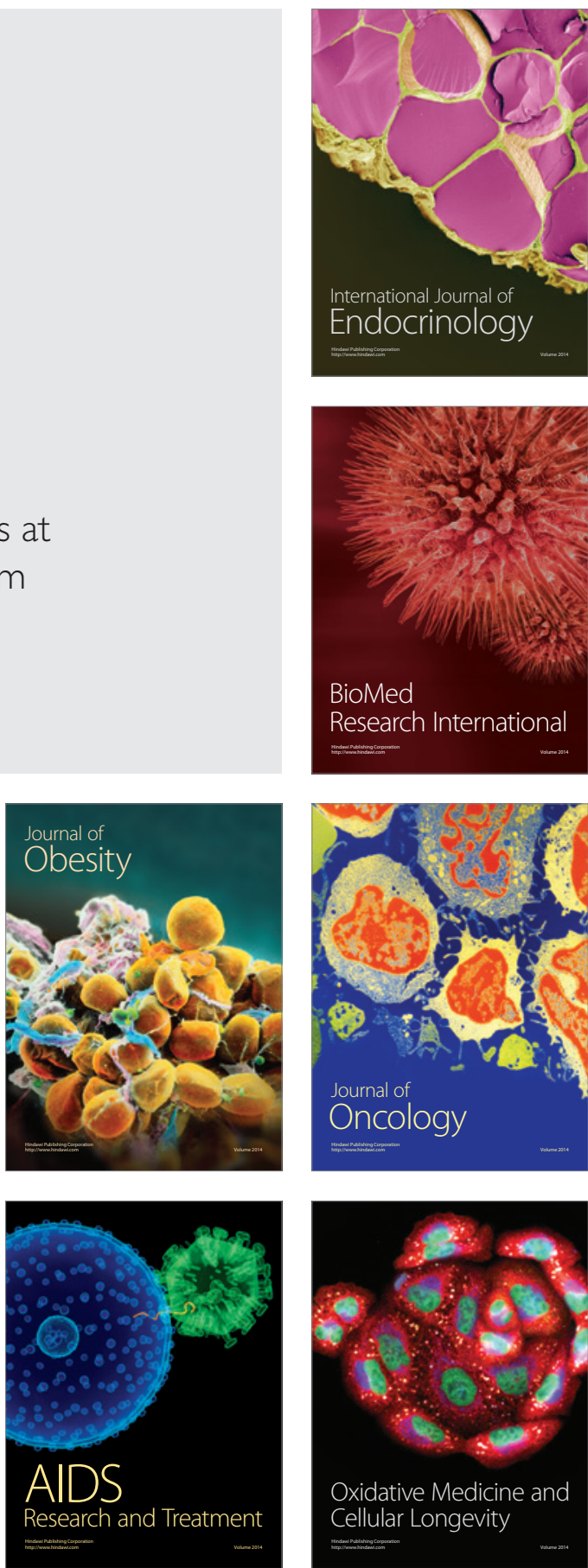